\title{
Marking fin spine of juvenile sturgeon (acipenseriformes: acipenseridae) using oxytetracycline and the comparing of growth performance
}

\author{
[Marcação da espinha da nadadeira de esturjão juvenil (Acipenseriformes: Acipenseridae) \\ usando-se oxitetraciclina e comparação do desempenho de crescimento] \\ S. Bakhshalizadeh ${ }^{*}$, A. Bani ${ }^{1,2}$, S. Abdolmalaki ${ }^{3}$, J.T. Ponce-Palafox ${ }^{4,5^{*}}$ \\ ${ }^{1}$ Department of Marine Sciences, Caspian Sea Basin Research Center, University of Guilan, Rasht, Iran \\ ${ }^{2}$ Department of Biology, Faculty of Science, University of Guilan, Rasht, Iran \\ ${ }^{3}$ International Sturgeon Research Institute, Agricultural Research, Education and \\ Extension Organization (AREEO), Rasht, Iran \\ ${ }^{4}$ National School of Fisheries Engineering - Aquaculture Bioengineering \\ Lab - Autonomous University of Nayarit - Nayarit, México \\ ${ }^{5}$ Laboratory of Water Quality and Experimental Aquaculture - University of \\ Guadalajara - Puerto Vallarta - Jalisco, México
}

\begin{abstract}
This study aimed to describe and validate the formation of the rings in the spine of the pectoral fin and to determine the coherence of the OTC mark with the rings of three species of Caspian Sea sturgeon, the Persian sturgeon (Acipenser persicus), the Starry sturgeon (Acipenser stellatus) and Ship sturgeon (Acipenser nudiventris). Validation was achieved by comparing the total radius of the fin spine of fish of known age after one and two years of growth with the measured radius of the first and second rings in the zone. There was no overlap between the measured radius for the first year and the increase for the second. The Ship sturgeon showed the largest width of the second ring followed by the Persian sturgeon and Stellate sturgeon. The results indicate that the highest growth parameter belongs to the juvenile Ship sturgeon. This research showed that chemically marking the fin spines of juvenile Acipenseridae leads to unbiased estimates and contributes to the knowledge of the population dynamics of these species. The study found that the combination of the dial ring of the pectoral fin spine with growth validated the age estimation in juvenile sturgeon Ship, Persian, and Starry sturgeon.
\end{abstract}

Keywords: Acipenser persicus, A. nudiventris, A. stellatus, annual radius

\section{RESUMO}

O objetivo deste estudo foi descrever e validar a formação dos anéis na espinha da nadadeira peitoral de três espécies de esturjão do mar Cáspio: o esturjão-persa (Acipenser persicus), o esturjão-estrelado (Acipenser stellatus) e o esturjão-de-navio (Acipenser nudiventris), bem como determinar a coerência da marca OTC com os anéis dessas três espécies. A validação foi alcançada comparando-se o raio total da espinha da nadadeira de peixes de idade conhecida, após um e dois anos de crescimento, com o raio medido do primeiro e segundo anéis na zona. Não houve sobreposição entre o raio medido no primeiro ano e o aumento no segundo. O esturjão-de-navio mostrou a maior largura do segundo anel, seguido pelo esturjãopersa e pelo esturjão-estrelado. Os resultados indicam que o maior parâmetro de crescimento pertence ao esturjão-de-navio juvenil. Esta pesquisa mostrou que a marcação química dos espinhos das nadadeiras de juvenis de Acipenseridae leva a estimativas imparciais e contribui para o conhecimento da dinâmica populacional dessas espécies. O estudo descobriu que a combinação do anel do mostrador da barbatana peitoral espinhal com o crescimento validou a estimativa de idade em esturjão-de-navio juvenil, esturjãopersa e esturjão-estrelado.

Palavras-chave: Acipenser persicus, A. nudiventris, A. stellatus, raio anual

Recebido em 19 de dezembro de 2020

Aceito em 11 de março de 2021

* Autor para correspondência (corresponding auhtor)

E-mail: jesus.ponce@usa.net and sh.bakhshalizadeh@guilan.ac.ir 


\section{INTRODUCTION}

A dramatic decline in diadromous species including sturgeon fish has been seen in the last century (Limburg and Waldman, 2009); the conservation of these endangered species requires an understanding of the life history traits. The life history character is dependent on age determination to estimate the appropriate conservation measures (Bakhshalizadeh et al., 2017), but often the validity of the age data, based on the analysis of hard calcific structures, has not been established. Errors in age determination cause overfishing and increased uncertainty in harvest guidelines (Beamish and Mcfarlane, 1983). Various methods including lengthfrequency analysis, mark and recapture studies, rearing studies and marginal increment analysis validate age estimation (Pearson, 1996; Panfili and Tomas, 2001; Crumpton et al., 2012).

Moreover, the estimation of sturgeon age is commonly made from cross-sections of the pectoral fin spines (Koch and Quist, 2007; Baremore and Rosati, 2014), based on the optical appearance of temporal cycle. These bony structures provide the greatest precision and accuracy for age estimation, and unlike other structures such as otoliths, opercles, clavicles, cleithra, and medial nuchals, they can be obtained without killing the fish (Brennan and Cailliet, 1989). Furthermore, the growth rate and accuracy of age estimation in sturgeon fish are critical to evaluating population abundance, age structure, recruitment, and mortality (Brennan \& Cailliet, 1989; Pauly et al., 2003; Balazik et al., 2012), this requires validation of the age. However, inaccurate age estimation can lead to estimation errors in the demographic variables of the population, the correct identification of the first and second annuli usually problematic in sturgeon fish (Stevenson and Secor, 2000). One way to validate annulus formation in fin spines is through oxytetracycline (OTC) mark analysis.

However, tetracycline labels are used for the first time to mark calcified structures for validating annuli (Weber and Rigway, 1967) and more recently oxytetracycline (OTC), alizarin red $\mathrm{S}$ (ARS), calcein and incorporation of ${ }^{137} \mathrm{Ba}^{2+}$ in pectoral fin spines are used as a time marker for several fish species (Brown and Powell, 2002; Mirali et al., 2017, Withers et al., 2019). Likewise, marking sturgeon species with OTC has been conducted in some research. In most surveys of sturgeon fish, the preferred method is injecting OTC, and is aimed at age and growth studies (Rein and Beamesderfer, 1994; Rossiter et al., 1995; Fielder, 2002). The first rings in sturgeon fish can produce a greater aging error than the older rings. Therefore, the correct identification of these first rings is essential to accurately determine the ages of the oldest fish. There is no data available to describe and validate annulus formation in any hard structure of any species of Persian sturgeon, Acipenser persicus, Starry sturgeon, Acipenser stellatus, and Ship sturgeon, Acipenser nudiventris. The above-mentioned species are limited to the Black, Azov, Aral, and Caspian Seas and are the most important sturgeon species inhabit in Caspian Sea fisheries (Pikitch et al., 2005). The largest populations are now concentrated in the Caspian Sea, from which they migrate into the Volga, Kura, Ural, Terek, Sulak, and Samur rivers (Berg, 1965). They also live in the Iranian rivers Sefid-Rud and Gorgan-chaii (Pourkazemi, 2006). These species are commercially the most common sturgeons in catches from Iranian coastal waters of the Caspian Sea, comprising more than $60 \%$ of the total sturgeon catch (Moghim et al., 2006; Fazli and Moghim, 2014).

Because of their status as the greatly threatened species in the International Union for Conservation of Nature (IUCN), the restocking is done by the Iranian fisheries program into both the Sefidrood and Gorganrood river estuaries of the south Caspian Sea for Acipenseridae process. The artificial juvenile fish should release with marks that are quickly identified at a low cost from wild fish and between released sites without scarifying fish. The aim of this study was to describe and validate annulus formation in sectioned pectoral fin spines and to reveal the consistency of the OTC mark with annuli. The validation was accomplished by comparing the total radius of the fin spine after one and two years old with the measured radius of the first and second zone annuli. In addition, we examined the pattern of growth in the fin spines to determine if the annuli zone measurements were stable or if they varied with fish species.

\section{MATERIALS AND METHODS}

A total of 19 Persian sturgeons, 20 Starry sturgeons, and 16 Ship sturgeons were collected from experimental tanks of Shahid beheshti hatchery with an initial weight of $67.10 \pm 26.49$, 
$61.49 \pm 32.51$, and $69.23 \pm 30.02 \mathrm{~g}$ respectively Samples were maintained in the fiberglass tanks $\left(1.5 \mathrm{~m}^{3}\right)$ with the density of $112.56 \mathrm{~g} \mathrm{~m}^{-3}$ under similar conditions of water quality (temperature $20.5 \pm 2.5^{\circ} \mathrm{C}$, dissolved oxygen $7.0 \pm 1.2 \mathrm{mg} \mathrm{L}^{-1}$, pH $7.2 \pm 0.8,12$ Light:12Dark) during 2.5 years, in the Fisheries Department, Faculty of Natural Resources, University of Guilan, Sowmeh-Sara, Iran. Fish were fed manually twice daily with a commercial diet (Biomar, Nersac, France; 35\% protein) throughout the experiment. The amount of feed was adjusted weekly to accommodate for the changes in fish weight. Experimental tanks were siphoned daily.

All fish were injected with a $25 \mathrm{mg} \mathrm{kg}^{-1}$ bodyweight dosage of oxytetracycline (OTC) into the red muscle under the lateral scute near the head (Monaghan, 1993). Due to variability in the breeding time of sturgeon species, injection was administrated in April, May, and June for the Persian sturgeon, Ship sturgeon, and Starry sturgeon, respectively. Injection repeated the second year as same as the first year. The total length, fork length, and total weight were measured for all fish. A part of the right pectoral fin spine was removed using methods described by Koch and Quist (2007) for detecting OTC marks three months after the second injection. Transverse sections were obtained using a fret saw and sections were polished with 250 and 400 grit sandpapers successively until the thickness of the sections reached $0.3-0.6 \mathrm{~mm}$. Sections were cemented to a glass slide and illuminated first with ultraviolet light to fluoresce the OTC marks and then with regular light to identify annuli. Procedures have been approved by the Authors' Institution's Ethics Committee, and care was taken to minimize the number of animals used.

For measuring the radius of first and second annuli to the nearest micrometer, an image was captured under $40 \times$ magnification and measured to the nearest micrometer across both axes right and left which is the radius of each concentric annulus from the focus to the outside edge of each translucent zone, each annuli comprised of an opaque zone by the side of a translucent zone (Brennan \& Cailliet 1989). Body weight increase (BWI), specific growth rate (SGR), and condition factor $(\mathrm{CF})$ were measured using the following formulae: $\mathrm{BWI}=\left(\mathrm{W}_{2}-\mathrm{W}_{1}\right) * 100 / \mathrm{W}_{1}$, where $\mathrm{W}_{1}$ and $\mathrm{W}_{2}$ indicate the initial and final weight $(\mathrm{g})$ respectively. $\mathrm{SGR}=\left(\mathrm{Ln} \mathrm{W}_{2}-\mathrm{Ln} \mathrm{W}_{1}\right) * 100 /$ Time (year); $\mathrm{CF}=100\left(\mathrm{~W} / \mathrm{FL}^{3}\right)$, where $\mathrm{W}$ is the total body weight and FL is the fork length $(\mathrm{cm})$. Parameters of the length-weight relationship were calculated by fitting the power function to length and weight data (Ricker, 1975): $\mathrm{W}=\mathrm{a} \mathrm{FL}{ }^{\mathrm{b}}$, where $\mathrm{W}$ is the gutted weight, $\mathrm{a}$ and $\mathrm{b}$ are regression constants and FL is the fork length.

Data were first checked for normality (Kolmogorov-Smirnov) and homogeneity of variances (Levene test). A paired sample T-test was used to determine if there was a difference (no overlap) between the first and second annular radius of the three species. To compare the width of both radius among the species, one-way ANOVA was used. This was followed by using pair-wise comparisons (Tukey's post hoc test). For comparing body weight increase (BWI), specific growth rate (SGR), and condition factor (CF) among species, one-way ANOVA was used. This was followed by using pair-wise comparisons (Tukey's post hoc test). All statistical analyses were performed with the SPSS 1997 (SPSS Base 7.5 for Windows Inc., Chicago IL, USA) software package and differences of $\mathrm{P}<0.05$ were considered statistically significant.

\section{RESULTS AND DISCUSSION}

In this study, it was found that Persian Sturgeon, Starry sturgeon, and Ship sturgeon fin spines can be marked with OTC. Results from the experiments showed that no discontinuous marks were seen in all three species individuals, and mark morphology was linked to the chemical nature (Figure 1). For the comparison of the mean width of the annuli of the three species, only the right axis was used (Table 1). There was no overlap between the measured radius for the first annual and those measured for the second increment radius. The width of the first annual increment was similar for the Persian sturgeon and Ship sturgeon and larger than Starry sturgeon $(\mathrm{P}<0.05)$. The width of the second annual increment differed considerably $(\mathrm{P}<0.05)$ among the species studied. The Ship sturgeon showed the largest width of the second annulus followed by the Persian sturgeon. (Figure 1). 
Marking fin spine...

Table 1. Parameter of morphometric, meristic, and growth (mean $\pm \mathrm{SD}$ ) compared among A. persicus, A. stellatus, and $A$. nudiventris sturgeon species, for 365 days

\begin{tabular}{lccc}
\multicolumn{1}{c}{ Parameter } & A. stellatus & A. persicus & A. nudiventris \\
\hline Fork length initial $(\mathrm{cm})$ & $30.45 \pm 3.62^{\mathrm{a}}$ & $27.73 \pm 3.52^{\mathrm{a}}$ & $28.43 \pm 4.16^{\mathrm{a}}$ \\
Fork length final $(\mathrm{cm})$ & $52.61 \pm 3.99^{\mathrm{a}}$ & $48.96 \pm 5.48^{\mathrm{a}}$ & $55.59 \pm 2.59^{\mathrm{a}}$ \\
Weight initial $(\mathrm{g})$ & $61.49 \pm 32.51^{\mathrm{a}}$ & $67.10 \pm 26.49^{\mathrm{a}}$ & $69.23 \pm 30.02^{\mathrm{a}}$ \\
Weight final $(\mathrm{g})$ & $486.43 \pm 250.23^{\mathrm{c}}$ & $678.16 \pm 242.20^{\mathrm{b}}$ & $866.81 \pm 86.80^{\mathrm{a}}$ \\
$\mathrm{y}=\mathrm{a} \mathrm{X}^{\mathrm{b}}$ & $\mathrm{y}=0.000005 \mathrm{X}^{4.0193}$ & $\mathrm{y}=0.0001 \mathrm{X}^{3.9646}$ & $\mathrm{y}=0.0001 \mathrm{X}^{3.9902}$ \\
$\mathrm{r}^{2}$ & 0.9729 & 0.9815 & 0.9912 \\
Body weight increase $(\mathrm{g})$ & $688.53 \pm 264.71^{\mathrm{c}}$ & $914.41 \pm 191.72^{\mathrm{b}}$ & $1,099.04 \pm 191.87^{\mathrm{a}}$ \\
Specific growth rate $(\% /$ day) & $0.55 \pm 0.09^{\mathrm{c}}$ & $0.63 \pm 0.06^{\mathrm{b}}$ & $0.69 \pm 0.02^{\mathrm{a}}$ \\
Condition factor & $0.33 \pm 0.04^{\mathrm{c}}$ & $0.55 \pm 0.07^{\mathrm{b}}$ & $0.65 \pm 00.04^{\mathrm{a}}$ \\
First annual radius $(\mu \mathrm{m})$ & $305.24 \pm 51.25^{\mathrm{b}}$ & $659.24 \pm 59.40^{\mathrm{a}}$ & $741.07 \pm 50.17^{\mathrm{a}}$ \\
Second annual radius $(\mu \mathrm{m})$ & $1,365.06 \pm 114.60^{\mathrm{c}}$ & $1,933.93 \pm 112.39^{\mathrm{b}}$ & $2,984.23 \pm 122.60^{\mathrm{a}}$ \\
Survival $(\%)$ & 100 & 100 & 100 \\
\hline
\end{tabular}

Means followed by a different letter(s) within each column (denoted by upper-case letters) are significantly different by Tukey's HSD test at $\mathrm{P}<0.05$.

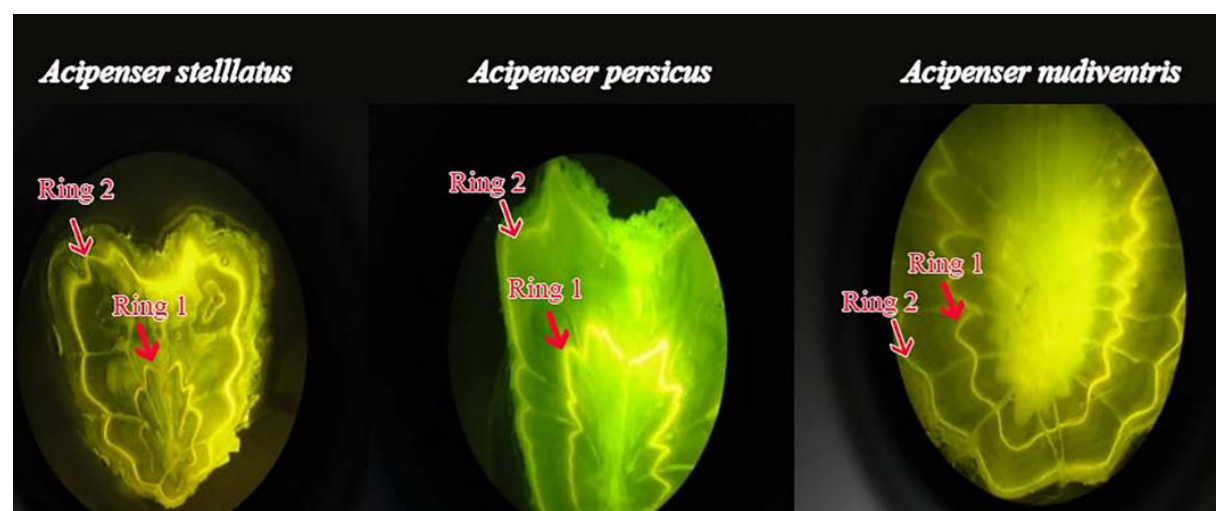

Figure 1. The presence of the OTC marks was appeared as a crisp distinct line under the ultraviolet light in pectoral fin spine of all species.

The Starry sturgeon had the smallest one. No mortality due to the OTC injection was occurred. In all cases, the presence of the OTC marks easily appeared as a crisp distinct line with ultraviolet light The highest BWI, SGR, and CF were observed for the juveniles of Ship sturgeon, Persian sturgeon, and Starry sturgeon, respectively. The results generally indicate that the highest parameter belongs to the juveniles of Ship sturgeon. The coefficient of determination $\left(\mathrm{r}^{2}\right)$ of the length-weight relationship was 0.982 for Acipenser persicus, 0.991 for Acipenser nudiventris, and 0.973 for Acipenser stellatus. The results of this study showed that growth parameters had a statistically significant difference among the species $(\mathrm{P}<0.05)$.

In our study, new techniques for chemically marking juvenile Acipenseridae provided with OTC and demonstrate the ability to detect these marks on pectoral fin spines by fluorescent microscopy. These marks are easily detected, and each marked structure is continuing, matches with annuli which can be assessed with similar results. Although vascular cavities are numerous in larvae and juveniles (Jatteau and Lochet, 2011), a good impregnation of the marker in the pectoral fin spine produce continuous marks, with a detrimental effect on mark quality and detection, so this information supports the use of nonlethal methods for analyzing OTC marks on these species. Moreover, OTC mark in the dorsal spine of juvenile yellow perch Perca flavescens and fin spines of juvenile mulloway Argyrosomus japonicas were seen obviously and when compared to otoliths support that there are no significant discrepancies between marks on otoliths and those on fin spines (Brown and Powell, 2002; Taylor et al., 2005). 
Although marks in the same dosage of OTC could be detected in $100 \%$ of pectoral fin spines of Persian Sturgeon, Acipenser persicus, Starry sturgeon, Acipenser stellatus, and Ship sturgeon, Acipenser nudiventris, detection of OTC marks in white sturgeon were $98 \%$ (Rien and Beamesderfer, 1994). Moreover, Speare (1992) used OTC marks to directly validate the frequency of growth increments on the fin spine of billfish. Validation of increment periodicity in earlyjuvenile and old-late age classes was a priority as mentioned by Campana (2001) because it inhibits errors in growth parameters. No mortality/negative impact on the fish were seen in our research which is supported by Collins and Smith (1996) in shortnose sturgeon's Scaphirhynchus platorynchus and Koch et al. (2011) in Pallid Sturgeon Schaphirhynchus albus. So, using pectoral fin spine was a viable alternative to otoliths for validation or markrecapture studies. In the case of the three studied species of the Caspian Sea, the differential relationship of the growth parameters and their relationship with the annual radius of each species corroborates that there is a significant variation of the annuli per year and between species, which has been determined for species in America (Andres et al., 2018).

Interpretation of annuli in pectoral spines to determine age in sturgeons was a proven method in various species of juveniles and adults in different parts of the world (Stevenson and Secor, 2000). The annual width of annuli in sectioned pectoral spines was associated with the highest growth of Ship sturgeon > Persian sturgeon > Starry sturgeon (Table 1). On the other hand, Kalish (2001) confirmed that the estimated age structure and growth rates of long longevity and slow-growing fish by OTC marking were accurate than the analysis of bomb radiocarbon method. In this study, it was shown that the application of OTC could improve the recognition of the annuli for the first and second years.

Further, the presence of numerous vascular channels and incorporation of secondary fin spines into the posterior lobe of the first spine could potentially lead to errors in age determination, making the first increment difficult to identify (Brennan and Cailliet, 1989). To obtain the most precision and accuracy ages, mean annular radius measurements should be used regularly to identify the first and second annuli.
There was a general agreement between the number of annual growth zones and OTC marks that were deposited similar to those reported by Rien and Beamesderfer (1994). In addition, because of no overlapping between the first and second annular radiuses measures in juvenile Persian sturgeon, Starry sturgeon, and Ship sturgeon, it is a useful criterion for age determination and applicable for restocking program and stock assessment. Very few studies have been conducted using OTC marks on sturgeon fish (Rien and Beamesderfer, 1994; Crumpton et al., 2012). Crumpton et al. (2012) demonstrates similar results of detecting OTC marks chemically in fin spines and otoliths of shortnose sturgeon, so using pectoral fin spine recommend a desirable method for endangered species like sturgeon fish. Because of some differences seen in the right and left axis pectoral fin spines, we suggest choosing the constant axis for measuring all fin sections. The dosage of OTC injection would not affect survival, as reported by Mcfarlane and King (2001).

Transversal sections of pectoral fin spines are the clear and reliable way to interpret annual annuli in Ship sturgeon, Persian sturgeon, and Starry sturgeon, however otoliths were irregularly shaped and their annuli were difficult to interpret (Stevenson and Secor, 2000). Nevertheless, difficulties in reading the fin sections were caused by damaged sections, abnormal or compressed bands on the anterior fin spine margin of older fish (Brennan and Cailliet, 1989; Murie et al., 2009). This research suggests that OTC can be detected clearly following OTC treatment. This work also represents a preliminary step in developing protocols for marking the fin spines of juvenile Ship, Persian, and Starry sturgeon prior to the initiation of a large-scale stocking program that utilizes OTC marks as a method of identification.

Using fin spines as the primary method for mark detection gives researchers the potential to evaluate stock status, habitat use, and life history of protected species that benefit from nonlethal methods of identification, including these sturgeon species in the Caspian Sea. Results also indicated that sturgeon fin spine is a uniquely powerful tool because it applies a nonlethal sampling technique to collect life history information that can be used to more effectively manage long-lived group of fishes like Caspian Sea sturgeon that face several anthropogenic 
threats. We suggest additional studies should be done to determine the efficacy of applying OTC marks during the embryonic and larval stages and the long-term retention of marks in the fin spines of Caspian Sea sturgeon to maximize the information on growth rate, movements, and maturation in the wild.

\section{CONCLUSIONS}

The present study showed that the combination of marking of the pectoral fin spine rings with growth validated the age estimate in the juveniles of Ship, Persian, and Starry sturgeons. This helps to analyse the width of the fin spine increments in the older mature sturgeons which is essential for determination of the growth trajectory and demographic variables of fish. It is suggested to compare the marks of used technique in this study with other techniques such as Calcein and alizarin red $\mathrm{S}$ (ARS) to evaluate their efficiency.

\section{ACKNOWLEDGEMENTS}

We also thank R. Rastin for his assistance in the preparation of fin spine sections. We would like to thank Mr. Mohamadi and Mr. Mosapour for the equipment. We also thank K. Bakhshalizadeh, S. Bakhshalizadeh, and A. Kor, for their spiritual support.

\section{REFERENCES}

ANDRES, M.J.; SLACK, W.T.; PETERSON, M.S. et al. Growth estimation of western population segment gulf sturgeon using length-atage and mark-recapture data. Trans. Am. Fish. Soc., v.147, p.139-150, 2018.

BAKHSHALIZADEH, S.; BANI, A.; ABDOLMALAKI, S. Identifying major events in two sturgeons' life using pectoral fin spine ring structure: exploring the use of a non-destructive method. Environ. Sci. Pollut. Res., v.2, p.1855418562, 2017.

BALAZIK, M.T.; MCININCH, S.P.; GARMAN, G.C. et al. Age and growth of Atlantic sturgeon in the James River, Virginia, 1997-2011. Trans. Am. Fish Soc., v.141, p.1074-1080, 2012.

BAREMORE, I.E.; ROSATI, J.D. A validated, minimally deleterious method for aging sturgeon. Fish. Bull., v.112, p.274-282, 2014.
BEAMISH, R.J.; MCFARLANE, G.A. The forgotten requirement for age validation in fisheries biology. Trans. Am. Fish. Soc., v.1121, p.735-743, 1983.

BERG, L.S. Freshwater fishes of the USSR and adjacent countries. 4.ed. Israel: Israel Program for Scientific, 1965. v.3, 1756p.

BRENNAN, J.S.; CAILLIET, G.M. Comparative age-determination techniques for white sturgeon in California. Trans. Am. Fish. Soc., v.118, p.296310, 1989.

BROWN, M.L.; POWELL, J.L. In-transit oxytetracycline marking, nonlethal mark detection, and tissue residue depletion in yellow perch. N. Am. J. Fish. Manag., v.22, p.236-242, 2002.

CAMPANA, S.E. Accuracy, precision and quality control in age determination including a review of the use and abuse of age validation methods. $J$. Fish. Biol., v.59, p.197-242, 2001.

COLLINS, M.R.; SMITH, T.I.J. Sturgeon fin ray removal is nondeleterious. N. Am. J. Fish. Manag., v.16, p.939-941, 1996.

CRUMPTON, R.L.; HENNE, J.P.; WARE, K.M. Marking otoliths and fin spines of juvenile shortnose sturgeon with oxytetracycline and the effects of water temperature during treatment. $N$. Am. J. Fish. Manag., v.32, p.523-527, 2012.

FAZLI, H.; MOGHIM, M. Length-weight relationships of five species of sturgeon in the Iranian waters of the Caspian Sea. J. Surv. Fish. Sci., v.1, p.56-58, 2014.

FIELDER, D.G. Methodology for immersion marking Walleye fry and fingerlings in oxytetracycline hydrochloride and its detection with fluorescence microscopy. Fish. Tech. Rep., 2002-1, 21p. 2002. (Michigan, Department of Natural Resources)

JATTEAU, P.; LOCHET, A. Mass marking in European sturgeon. In Biology and Conservation of the European Sturgeon Acipenser sturio L. 1758. Springer, Berlin. Heidelberg: Verlag, 2011. p.357-367.

KALISH, J. Use of the bomb radiocarbon chronometer to validate fish age. Canberra Australia: Fish Reserch and Development Corporation, 2001. (Report No. FRDC Project. 93/109). 
KOCH, J.D.; QUIST, M.C. A technique for preparing fin rays and spines for age and growth analysis. N. Am. J. Fish. Manag., v.27, p.782-784, 2007.

KOCH, J.D.; STEFFENSEN, K.D.; PEGG, M.A. Validation of age estimates obtained from juvenile Pallid Sturgeon Schaphirhynchus albus fin spines. J. Appl. Ichthyol., v.27, p.209-212, 2011.

LIMBURG, K.E.; WALDMAN, J.R. Dramatic declines in North Atlantic diadromous fishes. Bioscience, v.59, p.955-965, 2009.

MCFARLANE, G.A.; KING, J.R. The validity of the fin-ray method of age determination for lingcod (Ophiodonelongatus). Fish. Bull., v.99, p.459-464, 2001.

MIRALI, H.; BANI, A.; FASIHI, J. Application of enriched ${ }^{137} \mathrm{Ba}$ tracer to mark juvenile Persian sturgeon (Acipenser persicus). Environ. Biol. Fish., v.100, p.163-169, 2017.

MOGHIM, M.; KOR, D.; TAVAKOLIESHKALAK, M. et al. Stock status of Persian sturgeon (Acipenser persicus Borodin, 1897) along the Iranian coast of the Caspian Sea. J. Appl. Ichthyol., v.22, p.99-107, 2006.

MONAGHAN, J.P.J.R. Notes: comparison of calcein and tetracycline as chemical markers in summer flounder flounder. Trans. Am. Fish. Soc., v.122, p.298-301, 1993.

MURIE, D.J.; PARKYN, D.C.; KOENIG, C.C. et al. Evaluation of finrays as a non-lethal ageing method for protected goliath grouper Epinephelus itajara. Endang. Species Res., v.7, p.213-220, 2009.

PANFILI, J.; TOMAS, J. Validation of age estimation and back-calculation of fish length based on otoliths microstructures in tilapias (Pisces, Cichlidae). Fish. Bull., v.99, p.139-150, 2001.

PAULY, D.; ALDER, J.; BENNETT, E. et al. The future for fisheries. Science, v.302, p.1359-1361, 2003.
PEARSON, D.E. Timing of hyaline-zone formation as related to sex, location, and year of capture in otoliths of the widow rockfish, Sebastes entomelas. Fish. Bull., v.94, p.190-197, 1996.

PIKITCH, E.K.; DOUKAKIS, P.; LAUCK, L. et al. Status, trends and management of sturgeon and paddlefish fisheries. Fish Fish., v.6, v.233-265, 2005.

POURKAZEMI, M. Caspian Sea sturgeon conservation and fisheries: past present and future. J. Appl. Ichthyol., v.22, p.12-16, 2006.

RICKER, W.E. Computation and interpretation of biological statistics of fish population. J. Fish. Res. Board. Can., v.19, p.382, 1975.

RIEN, T.A.; BEAMESDERFER, R.C. Accuracy and precision of white sturgeon age estimates from pectoral fin spines. Trans. Am. Fish. Soc., v.123, p.255-265, 1994.

ROSSITER, A.D.L.; NOAKES, G.; BEAMISH, F.W.H. Validation of age estimation for the lake sturgeon. Trans. Am. Fish. Soc., v.124, p.777-781, 1995.

SPEARE, P. A technique for tetracycline injecting and tagging billfish. Bull. Mar. Sci., v.51, p.197-203, 1992.

STEVENSON, J.T.; SECOR, D.H. Age determination and growth of Hudson River Atlantic sturgeon (Acipenser oxyrinchus). Fish Bull., v.98, p.153-166, 2000.

TAYLOR, M.D.; FIELDER, D.S.; SUTHERS, I.M. Batch marking of otoliths and fin spines to assess the stock enhancement of Argyrosomus japonicus. J. Fish Biol., v.66, p.1149-1162, 2005.

WEBER, D.; RIGWAY, G.J. Marking Pacific salmon with tetracycline antibiotics. J. Fish Res. Board. Can., v.24, p.849-865, 1967.

WITHERS, J.L.; MARKLEY, N.; DAVIS, L. et al. Labeling calcified structures in young lake sturgeon: a comparison of oxytetracycline hydrochloride, alizarin Red S, and calcein. N. Am. J. Fish. Manag., v.39, p.1217-1226, 2019. 